\title{
THE IMPROVEMENT AND AUTOMATION OF THE PROCESSES OF THE PRODUCTS RECEPTION AND ASSEMBLY IN THE TRADE-WAREHOUSE COMPLEX
}

\author{
Yu.V. Podpovetnaya, 2 , y-u-l-i-a-v-a-l@mail.ru, \\ A.M. Najmiddinov ${ }^{3}$, asadullo-tj@mail.ru, \\ L.Yu. Ovsyanitskaya1, larovs@rambler.ru, \\ A.D. Ovsyanitskiy2, alexao12@rambler.ru \\ ${ }^{1}$ Financial University under the Government of the Russian Federation (Chelyabinsk branch), \\ Chelyabinsk, Russian Federation, \\ ${ }^{2}$ South Ural State University, Chelyabinsk, Russian Federation, \\ ${ }^{3}$ Tajik State Finance and Economics University, Dushanbe, Republic of Tajikistan
}

The logistical processes of the enterprise require constant improvement and introduction of corresponding changes. The study of the activities of the trade and warehouse complex showed that the main role is played by the system for managing the processes of receiving and assembling goods. Therefore, in the article, special importance is given to the process of automation and development of information support for a system for managing these data in the trade and warehouse complex.

The analysis and modeling of the existing processes of the company on the basis of two approaches of business modeling has been carried out. It is shown that the object approach allows to build a more stable to changes system, has more correspondences with the existing structure of the organization. The article presents that the functional modeling is optimal when the organizational structure undergoes changes or is in the process of correction. Using the graphical language IDEF0, the analyzed system is represented as a set of interrelated functions (function blocks).

To improve the efficiency of storage processes, based on the AS-IS model, a TO-BE model was built and the efficiency of the developed model was evaluated. During the TO-BE model study, the advantages of the embedded device for automating the processes of receiving and assembling goods were proved, as well as the advantages of the new model in terms of key indicators: the time of work, labor productivity, costs, the number of errors in the assembly of goods, the number of staff.

The substantiation of a method of automation of warehouse processes of reception and assembly of goods is presented, the choice of the brand of the device of trade and warehouse activity is made. To illustrate the choice of software, basic software platforms were considered and optimal software was identified to ensure the efficiency of warehouse processes. The choice of software was made taking into account the possibility of integrating the data collection terminal with the $1 \mathrm{C}$ system used in the company's work. The capabilities of the selected driver, its advantages and functional properties have been analyzed.

Keywords: information support, automation of warehouse processes, trade and warehouse complex, logistics processes.

\section{Introduction. Statement of the problems}

The warehousing operations in the activities of any company are very important and require much attention and research. Especially in this activity it is possible to single out the processes of receiving and assembling goods, since every day it is necessary to continuously consider hundreds and thousands of goods. The assembly is complicated by the fact that different types of goods must be completed in one order. If you do these operations manually, this leads to shortages, delays and re-sortings. Receiving goods manually causes theft, improper placement by warehouse storage areas, and slows down the work process. These errors lead to a loss of funds and the company's time, are forced to come back again and again to correct them. Immediate impact on them has a human factor, the lack of automation of the processes of receiving and assembling goods, accounting for goods in the warehouse. Therefore, the solution to the problem of improving and automating the process of receiving and assembling goods in the trade and warehouse complex is an urgent issue [1]. 
In order to decide the above-mentioned problem, the following problems have been defined and solved in the article:

- the analysis of the company's activities, its organizational structure, regulations and processes in the logistics department has been performed;

- the AS-IS model of the logistics process and the decomposition diagram of the AS-IS model of receiving and assembling goods in the warehouse has been built;

- to improve the efficiency of storage processes on the basis of the AS-IS model, the TO-BE model has been constructed and an evaluation of the effectiveness of the developed TO-BE model has been presented;

- the method of warehouse processes for receiving and assembling goods is justified the selection of software (software) is made [2].

\section{The analysis and the modeling of existing company processes}

More details on the activities of the logistics department, which is carried out on the territory of the trade and warehouse complex (TWC). Warehouses are an important element in TWC. A rational approach to the implementation of warehouse operations is the key to the profitability of the entire trading and warehousing complex. Therefore, organizing the logistics process, it is necessary to pay attention to such factors as:

- the rational layout of the warehouse with the allocation of working areas, which contribute to the improvement of the process of assembling and receiving goods;

- the effective use of space in the storage room when arranging racks and shelves for storage;

- the use of special equipment that is capable of performing various operations, which makes it possible to reduce the number of lifting and transporting machines;

- the reduction of transportation routes inside the warehouse, which allows to reduce the throughput of the warehouse, etc.

To build the functional model of AS-IS it is customary to use two approaches to business modeling. Each of them has its own advantages. The object approach allows to build a more stable to changes system, has more correspondences with the existing structure of the organization [3-5]. Functional modeling is well suited when the organizational structure is subject to change or is in the process of adjustment. The approach of functions is better understood by performers when they receive information about their work at the moment.

Using the graphical language IDEF0, the analyzed system is presented to analysts and developers as a set of interrelated functions (function blocks). As you know, modeling with the help of IDEF0 tools is the first stage in the study of any organization system [6].

After the construction, the context diagram is detailed using the first-level decomposition diagram. Detailing the business processes allows you to identify the shortcomings of the organization, even where functionality at first glance seems obvious. Decomposing the main block of the diagram, the following important processes are distinguished: company management; logistics; accounting and finance; purchase; marketing and sales. Fig. 1 shows the decomposition diagram of the AS-IS model.

Thus, the most important processes requiring automation, such as the receipt of goods and the assembly of goods occurring in the logistics department, are identified in the analysis of the efficiency of existing processes, based on the AS-IS functional model and the AS-IS decomposition model. Also, the minuses of the AS-IS model in these two processes have been defined processes:

1 ) in the process of acceptance of the goods at the stage of registration of the invoice in the 1C system, the expiration dates, invoices, dates, full names, the number of the consignment note, etc., are manually entered;

2 ) in the process of assembling goods, all assembly notes are on paper, the data on the executors and the list of goods on the waybill are marked manually, then they entered into the program by the operator;

3) there can be re-sortings and shortages, because Large amounts of work entail errors when searching for the right product;

4) reduced speed and productivity of assembly of goods on consignment notes due to the presence of human factors;

5) there is no control over the correct placement of goods received in the warehouse [7].

Thus, we propose a solution and construct TO-BE model based on the identified shortcomings. 


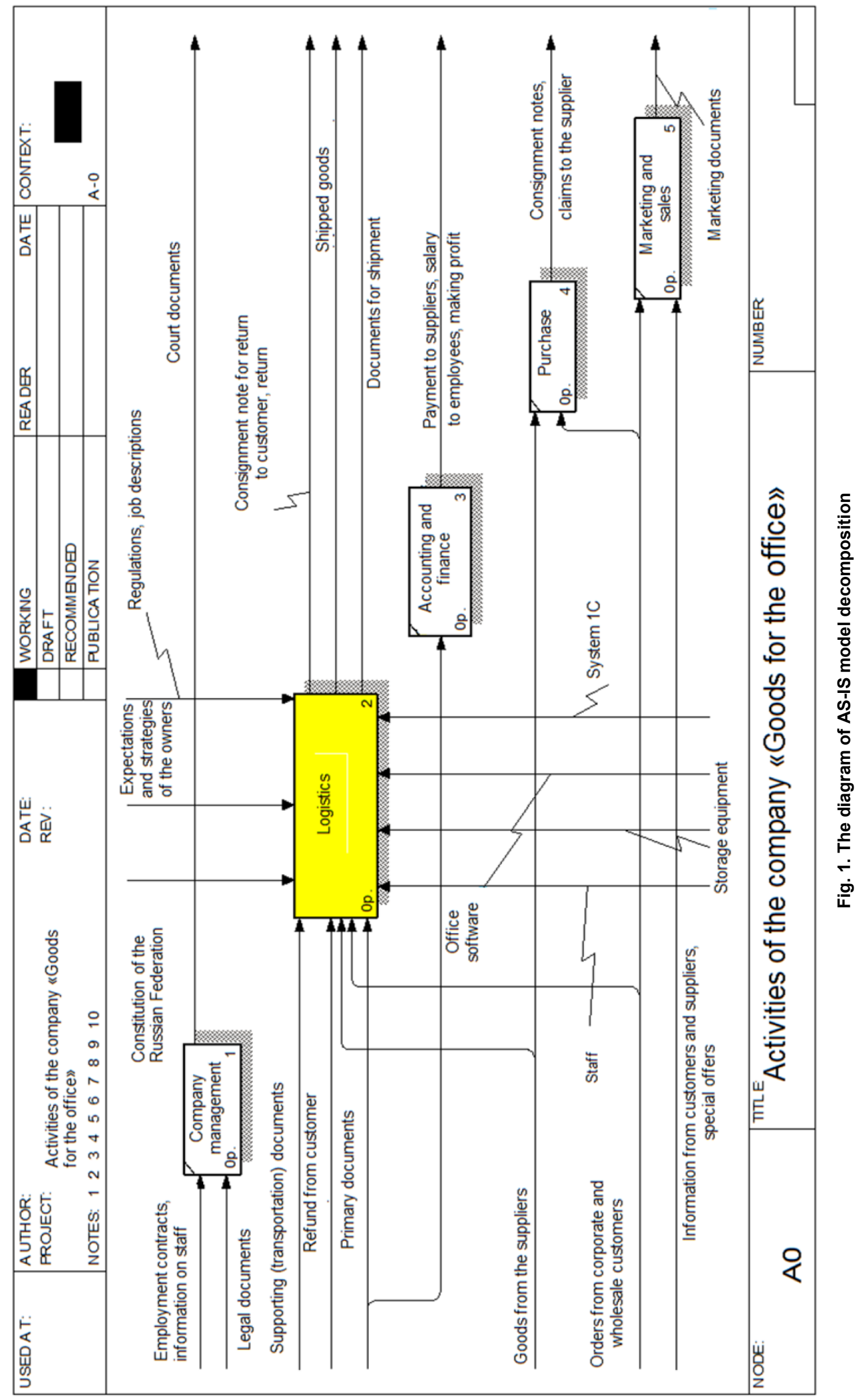




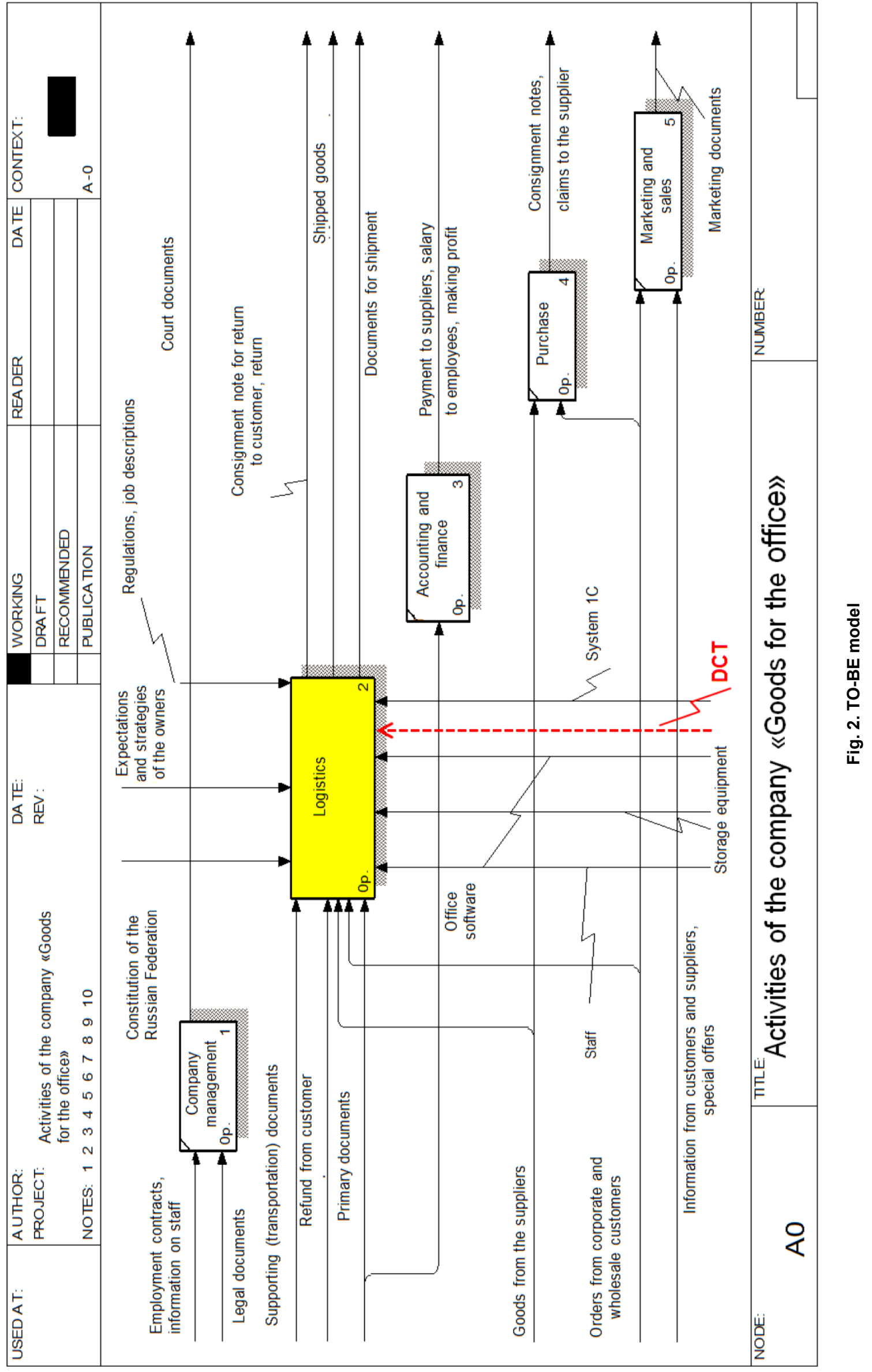




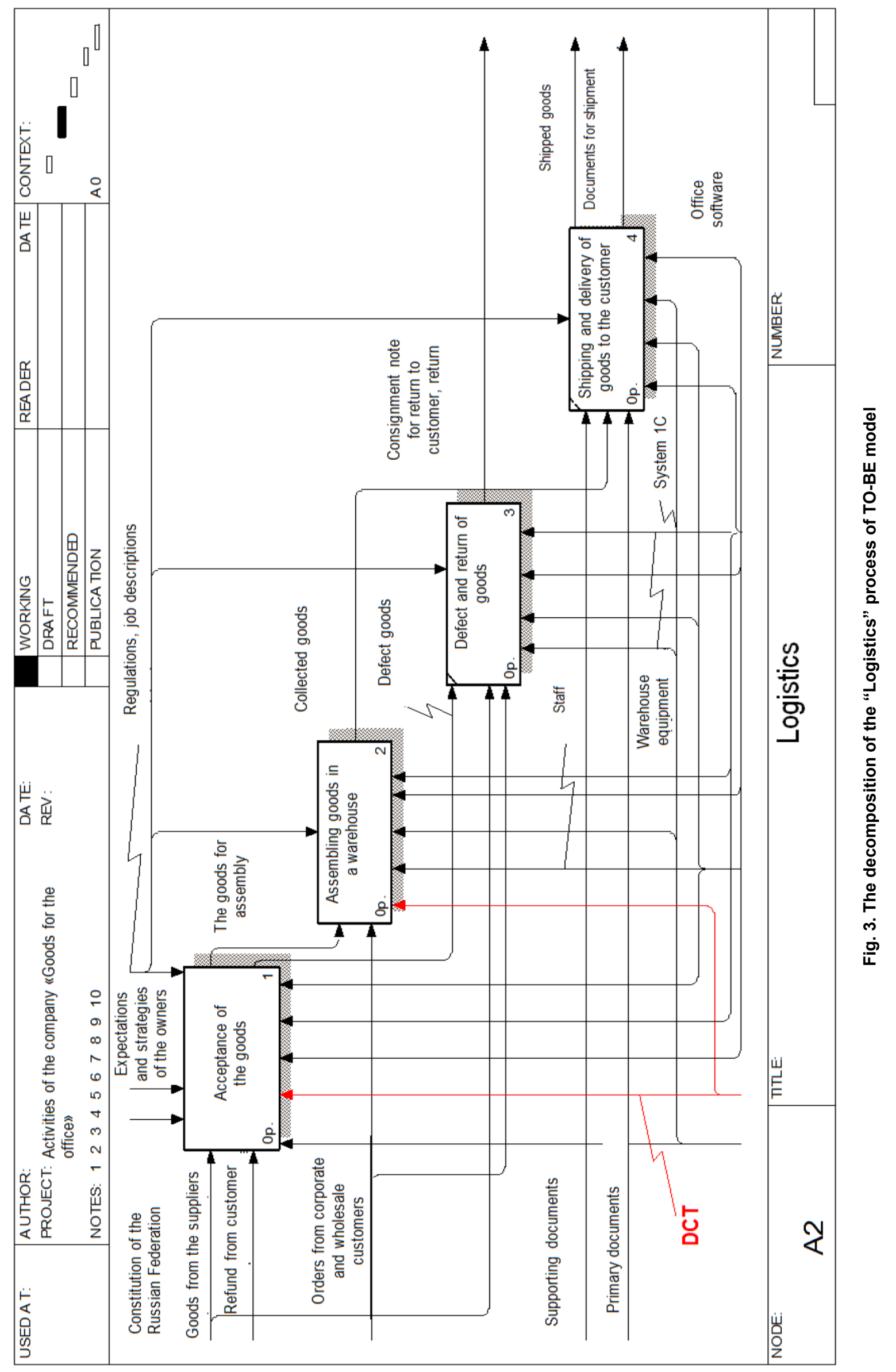




\section{The description of TO-BE functional model and choice of equipment}

The analysis showed that one of the solutions to the identified problems and the most economical from the point of view of automation of the processes of receiving and assembling goods will be the introduction of the data collection terminal (DCT) into the logistics department. The main purpose of the DCT is the quick and convenient collection, processing and transmission of information about the cargo or goods in the company's information system, as well as the use of bar coding [8].

There are different categories of data collection terminal. Each of the categories of terminals for data collection has certain constructive and functional features that make them the best kind of devices in these conditions. Selecting a particular type of terminals follows, clearly presenting the conditions under which it will be used.

During the study of the TO-BE model, the advantages of the embedded device for automating the processes of receiving and assembling goods were revealed:

1) the work time of the employees using the DCT is reduced;

2) the labor productivity is increased;

3) with the disappearance of paper carriers, the cost of paper is reduced;

4) with the elimination of the human factor, various constant errors of employees are disappeared.

TO-BE model has been formed based on the study of the AS-IS model and the processing of its shortcomings (Fig. 2). The decomposition of the logistic process of the TO-BE model is presented in Fig. 3.

As a result of comparing the AS-IS and the TO-BE models, the advantages of the new model are revealed, which are presented in Table 1.

The comparison of AS-IS and TO-BE models

Table 1

\begin{tabular}{|l|l|l|}
\hline \multicolumn{1}{|c|}{ The indicators } & \multicolumn{1}{c|}{ AS-IS model } & \multicolumn{1}{c|}{ TO-BE model } \\
\hline Productivity & $\begin{array}{l}50 \text { consignment notes } \\
\text { for } 8 \text { hours }\end{array}$ & $\begin{array}{l}66 \text { consignment notes } \\
\text { for } 8 \text { hours }\end{array}$ \\
\hline The paper costs & 44650 rubles & 23825 rubles \\
\hline $\begin{array}{l}\text { The number of errors in the assembly } \\
\text { of goods (re-sorting, shortage) }\end{array}$ & $\begin{array}{l}\text { On 50 consignment notes, } \\
\text { an average of 5 errors are made }\end{array}$ & No errors \\
\hline $\begin{array}{l}\text { The number of staff required } \\
\text { to assemble }\end{array}$ & 10 people & 5 people \\
\hline
\end{tabular}

Thus, the introduction of AS-IS model increases the labor productivity, cuts the paper costs by half (since paper carriers disappear for assembly), eliminates the human factor (which reduces the likelihood of errors in the assembly of goods on invoices), reduces the required number of personnel (which allow employees to re-qualify for other types of work in the organization) and the most important advantage is the increasing the manageability of the warehouse.

\section{The choice of software for the implementation of the trade and warehouse activities}

The automation of the warehouse allows to ensure the most efficient management of all its processes. This approach serves as a guarantee of stable business development. The universal warehouse management automation system provides an operational accounting of products and detailing the placement of goods in warehouses. The list of tasks it implements also includes inventory control and correctness of product write-off, reservation management. Such a program is designed specifically for the management of warehouse logistics.

Automation of warehouse management is provided through the introduction of specialized software products. The software product will allow automating all existing processes in a short time. For the selection of software analysis of existing operating systems (drivers). The results of the analysis showed that the capabilities of the wi-fi data acquisition terminal driver are most suitable for working in the warehouse, since it is the only driver that works with $1 \mathrm{C}$ : Enterprise 8. Together with the software, manufacturers offer a set of maintenance treatments for the supported configuration [9-11]. 


\section{Краткие сообщения}

The advantages of the software are:

1. There is no need to change the configuration of $1 \mathrm{C}$.

2. The address storage. Each driver is supplied with a configurator (mobile development environment), which allows changing the processing logic of the documents and the user interface of the DCT, as well as developing the new operations.

3. The remote work. To work with DCT that are not connected to that particular computer on which $1 \mathrm{C}$ works, a wired version of the driver provides a special synchronization utility that copies files from the DCT to a computer with $1 \mathrm{C}$ and vice versa. In wireless versions of the driver, the exchange takes place directly over the Internet, by connecting via Wi-Fi or locally via the cradle (when inserted into the cradle, the DCT starts to see the network).

4. The automatic loading and unloading of documents in 1C. It can be possible to customize the selection to work on the DCT and automatically to download, upload, fill any warehouse documents $1 \mathrm{C}$.

5. The teamwork with the documents. It is permissible the simultaneous work with one document on several DCT.

6. A free configurator (mobile development environment) is supplied with each driver, which allows changing the processing logic of the documents and the user interface of the DCT, as well as developing new operations.

7. Using the Mobile SMARTS 2008 platform, the mobile development environment is supplied with the driver, which allows changing the processing logic of the documents and the user interface of the DCT, as well as developing new operations.

8. The driver is protected by a software license, which is issued separately for each terminal in accordance with its unique code.

The additional functional characteristics of the driver are given in Table 2.

The driver functional characteristics

\begin{tabular}{|l|l|}
\hline \multicolumn{1}{|c|}{$\begin{array}{c}\text { The needing to make changes } \\
\text { to the 1C configuration }\end{array}$} & \multicolumn{1}{c|}{ Not required } \\
\hline The uploading documents to the radio terminal & $\begin{array}{l}\text { For automatic document exchange, you need } \\
\text { a module for automatic loading, unloading }\end{array}$ \\
\hline The remote access to 1C & $\begin{array}{l}\text { It is not required. Everything works online, } \\
\text { through a terminal server }\end{array}$ \\
\hline The supported volumes of the directory & All nomenclature is taken from the 1C database \\
\hline Many documents on one terminal & It is possibly \\
\hline The collective work with documents & $\begin{array}{l}\text { To work together with documents you need } \\
\text { a teamwork module }\end{array}$ \\
\hline Mobile printing & Print requires a printing module \\
\hline $\begin{array}{l}\text { The support of weighted goods, characteristics, } \\
\text { series, serial numbers }\end{array}$ & It is possibly \\
\hline
\end{tabular}

\section{Conclusion}

Based on the analysis of the shortcomings of the AS-IS model, the TO-BE model was built for automation of the logistics department and the goods reception and assembly processes, in which it is proposed to implement a data collection terminal. The models AS-IS and TO-BE are compared. The implementation of the TO-BE process increases the labor productivity, reduces the cost of paper by half, errors in assembly disappear, because the human factor is removed, the work time is reduced, the number of personnel is reduces, and the most important advantage is the increase in warehouse manageability.

The selection of software was made for the integration of the data acquisition terminal with the $1 \mathrm{C}$ system used in the company's work. The capabilities of the selected driver, its advantages and functional properties are described.

The requirements to the implemented equipment are revealed, such as:

1. The optimum cost of equipment.

2. The ease of use. 
3. The reliability and quality.

4. The resistance to external influences.

5. The modernity (support wi-fi).

6. The speed of action.

As a result, the automated system for warehouse accounting of goods has been created, which ensures an increase in the efficiency of the logistics department in the company's trade and warehouse complex. It is established that the implementation of the data collection terminal allows to solve four main problems in the warehouse accounting of goods: theft of goods; shortage, re-sorting; loss of time; low employee efficiency.

The automation of the reception and assembly of goods allows:

1. To enter the data on the completed requests into the $1 \mathrm{C}$ system automatically.

2. To enter the data about the accepted goods into the $1 \mathrm{C}$ system automatically.

3. Collect goods for customer requests without paper carriers.

4. To carry out the account of the goods automatically.

5. To perform the correct zoning of the goods in the warehouse.

\section{References}

1. Volgin V.V. Sklad: organizatsiya, upravlenie, logistika [Warehouse: Organization, Management, Logistics]. Moscow, Dashkov and K. Publ., 2015. 724 p.

2. Klyuyev A.S., Rotach V.Ya., Kuzishchyn V.F. Avtomatizatsiya nastroyki sistem upravleniya [Automation of Tuning of Control Systems]. Moscow, Alliance Publ., 2015. 272 p.

3. Podpovetnaya Yu.V., Bulgakova M.V. [Analysis of Commercial Activity of Large Retail Chains of Household Appliances Stores]. Management in Modern Systems, 2014, no. 4 (4), pp. 55-59. (in Russ.)

4. Pereverzev P.P. (Ed.) Informatsionnoe obespechenie malogo innovatsionnogo biznesa [Information Support of Small Innovative Business: Collective Monograph]. Moscow, Pero Publ., 2016. 164 p.

5. Bunova E.V. (Ed.) Avtomatizatsiya biznes-protsessov kompaniy v sootvetstvii s kontseptsiey CRM [Automation of Business Processes of Companies in Accordance with the Concept of CRM: Collective Monograph]. Moscow, Pero Publ., 2017. 134 p.

6. Dustin E., Reshka D., Paul D. Testirovanie programmnogo obespecheniya. Vnedrenie, upravlenie $i$ avtomatizatsiya [Software Testing. Implementation, Management and Automation]. Moscow, Lori Publ., 2013. 567 p.

7. Johnson D.S., Wood D.F., Wordlaw DL, Murphy-Jr P.R. (Ed.) Sovremennaya logistika [Modern Logistics]. Moscow, Williams Publ., 2015. 624 p.

8. Informatsionnoe obespechenie. Proekt po avtomatizatsii upravleniya srednim predpriyatiem [Information Support. Project on Automation of Medium Enterprise Management]. Available at: http://kit-project.narod.ru/4.6.htm (accessed 5 September 2018).

9. Lubnina A.A., Shinkevich M.V., Yalunina E.N., Gaidamashko I.V., Savderova A.F., Komissarova M.A. Innovative Strategy for Improving the Efficiency of Industrial Enterprises Management. Revista ESPACIOS, 2018, vol. 39, no. 09. Available at: http://www.revistaespacios.com/a18v39n09/ a18v39n09p25.pdf.

10. Zijm H. et al. Operations, Logistics and Supply Chain Management: Definitions and Objectives. Springer, Cham, 2018, pp. 27-42. DOI: 10.1007/978-3-319-92447-2_3.

11. Richards G. Warehouse Management: a Complete Guide to Improving Efficiency and Minimizing Costs in the Modern Warehouse. Kogan Page Publishers, 2017. 513 p.

Received 28 August 2018 


\title{
СОВЕРШЕНСТВОВАНИЕ И АВТОМАТИЗАЦИЯ ПРОЦЕССА ПРИЕМА И СБОРКИ ТОВАРОВ В ТОРГОВО-СКЛАДСКОМ КОМПЛЕКСЕ
}

\author{
Ю.В. Подповетная ${ }^{1,2}$, А.М. Наджмиддинов ${ }^{3}$, \\ Л.Ю. Овсяницкая ${ }^{1}$, А.Д. Овсяницкий ${ }^{2}$ \\ ${ }^{1}$ Финансовый университет при Правительстве РФ (Челябинский фрилиал), \\ 2. Челябинск, Россия, \\ ${ }^{2}$ Южно-Уральский государственный университет, г. Челябинск, Россия, \\ ${ }^{3}$ Таджикский государственный финансово-экономический университет, \\ е. Душанбе, Республика Таджикистан
}

Логистические процессы предприятия требует постоянного совершенствования и внесения соответствующих изменений. Исследование деятельности торгово-складского комплекса показало, что основную роль играет система управления процессами приема и сборки товара. Поэтому в статье особое значение уделено процессу автоматизации и разработки информационного обеспечения для системы управления данными процессами в торгово-складском комплексе.

Проведен анализ и моделирование существующих процессов компании на основе двух подходов бизнес-моделирования. Объектный подход дает возможность построить более устойчивую к изменениям систему, имеет больше соответствий с существующей структурой организации. Функциональное моделирование оптимально в тех случаях, когда организационная структура подвергается изменениям или находится в процессе корректирования. С помощью графического языка IDEF0 анализируемая система представлена как набор взаимосвязанных функций (функциональных блоков).

С целью повышения эффективности складских процессов на основании модели AS-IS построена модель ТО-ВЕ и проведена оценка эффективности разработанной модели. В ходе изучения модели ТО-ВЕ выявлены достоинства внедренного прибора для автоматизации процессов приема и сборки товара, а также достоинства новой модели по основным показателям: время работы, производительность труда, затраты, количество ошибок при сборке товара, численность персонала.

Представлено обоснование метода автоматизации складских процессов приема и сборки товара, произведен выбор марки прибора торгово-складской деятельности. Для иллюстрации выбора программного обеспечения (ПО) рассмотрены базовые программные платформы и выявлено оптимальное ПО, обеспечивающее эффективность складских процессов. Выбор ПО произведен с учетом возможности интеграции терминала сбора данных с системой 1С, используемой в работе компании. Проанализированы возможности выбранного драйвера, его преимущества и функциональные свойства.

Ключевые слова: информачионное обеспечение, автоматизация складских прочессов, торгово-складской комплекс, логистические прочессы.

\section{Лuтература}

1. Волгин, В.В. Склад: организачия, управление, логистика / В.В. Волгин. - М.: Дашков и К., 2015. $-724 c$.

2. Клюев, А.С. Автоматизачия настройки систем управления / А.С. Клюев, В.Я. Ротач, В.Ф. Кузищин. - М.: Альянс, 2015. - 272 с.

3. Подповетная, Ю.В. Анализ коммерческой деятельности крупных розничных сетей магазинов бытовой техники / Ю.В. Подповетная, М.В. Булгакова // Управление в современных системах. - 2014. - № 4 (4). - C. 55-59.

4. Информационное обеспечение малого инноваџионного бизнеса: коллектив. моногр. / под ред. проф. П.П. Переверзева. - М.: Перо, 2016. - 164 с. 
5. Автоматизащия бизнес-процессов компаний в соответствии с концепџией CRM: коллектив. моногр. / под. ред. Е.В. Буновой. - М.: Перо, 2017. - 134 с.

6. Дастин, Э. Тестирование программного обеспечения. Внедрение, управление и автоматизачия / Э. Дастин, Д. Рэшка, Д. Пол. - М.: Лори, 2013. - 567 с.

7. Современная логистика / под ред. Джснсона Д.С., Вуда Д.Ф., Вордлоу Д.Л., Мерфи-мл. П.Р. М.: Вильямс, 2015. - 624 с.

8. Информационное обеспечение. Проект по автоматизации управления средним предприятием. - http://kit-project.narod.ru/4.6.htm (дата обращения: 05.09.2018).

9. Innovative strategy for improving the efficiency of industrial enterprises management / A.A. Lubnina, M.V. Shinkevich, E.N. Yalunina et al. // Revista ESPACIOS. - 2018. - Vol. 39, no. 09.

10. Operations, Logistics and Supply Chain Management: Definitions and Objectives / H. Zijm et al. // Operations, Logistics and Supply Chain Management. - Springer, Cham, 2018. - P. 27-42.

11. Richards, G. Warehouse management: a complete guide to improving efficiency and minimizing costs in the modern warehouse / G. Richards. - Kogan Page Publishers, 2017. - 513 p.

Подповетная Юлия Валерьевна, д-р пед. наук, доцент, зав. кафедрой математики и информатики, Финансовый университет при Правительстве РФ (Челябинский филиал); профессор кафедры русского языка как иностранного, Южно-Уральский государственный университет, г. Челябинск; y-u-1-i-a-v-a-1@mail.ru.

Наджмиддинов Асадулло Мирзоевич, канд. физ.-мат. наук, зав. кафедрой математического моделирования и информации, Таджикский государственный финансово-экономический университет, г. Душанбе, Республика Таджикистан; asadullo-tj@mail.ru.

Овсяницкая Лариса Юрьевна, канд. техн. наук, доцент кафедры математики и информатики, Финансовый университет при Правительстве РФ (Челябинский филиал), г. Челябинск; larovs@rambler.ru.

Овсяницкий Алексей Дмитриевич, студент Высшей школы электроники и компьютерных наук, Южно-Уральский государственный университет, г. Челябинск; alexao12@rambler.ru.

Поступила в редакцию 28 августа 2018 г.

\section{ОБРАЗЕЦ ЦИТИРОВАНИЯ}

The Improvement and Automation of the Processes of the Products Reception and Assembly in the TradeWarehouse Complex / Yu.V. Podpovetnaya, A.M. Najmiddinov, L.Yu. Ovsyanitskaya, A.D. Ovsyanitskiy // Bectник ЮУрГУ. Серия «Компьютерные технологии, управление, радиоэлектроника». - 2018. - Т. 18, № 4. C. $160-169$. DOI: $10.14529 /$ ctcr 180416

\section{FOR CITATION}

Podpovetnaya Yu.V., Najmiddinov A.M., Ovsyanitskaya L.Yu., Ovsyanitskiy A.D. The Improvement and Automation of the Processes of the Products Reception and Assembly in the Trade-Warehouse Complex. Bulletin of the South Ural State University. Ser. Computer Technologies, Automatic Control, Radio Electronics, 2018, vol. 18 , no. 4 , pp. $160-169$. DOI: $10.14529 /$ ctcr180416 